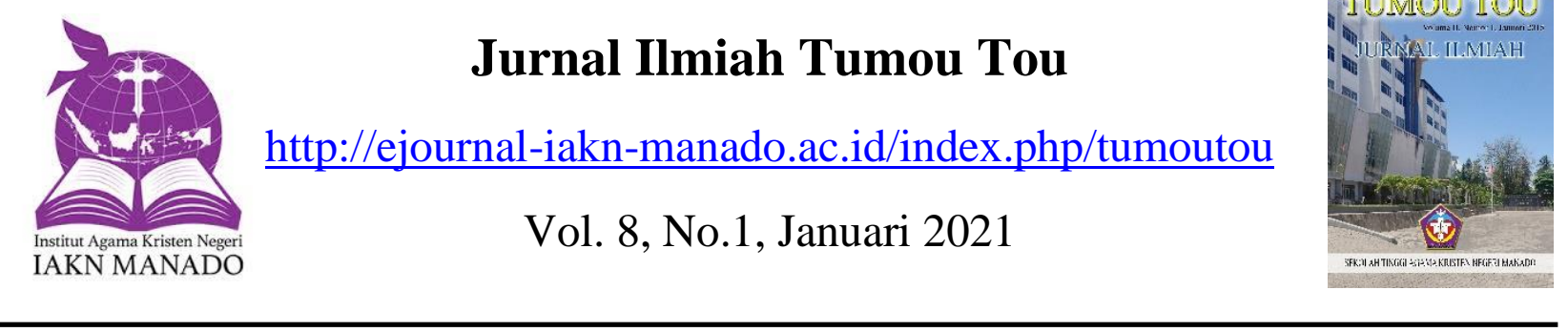

\title{
Transformasi Pengucapan Syukur: Identitas dan Relasi Sosial Era Pandemi Covid-19 di Tomohon
}

\author{
Wolter Weol $^{1}$, Nency Aprilia Heydemans ${ }^{2}$, Fienny Maria Langi ${ }^{3}$ \\ ${ }^{1}$ IAKN Manado (Dosen Program Studi Pendidikan Agama Kristen) \\ ${ }^{2}$ IAKN Manado (Dosen Program Studi Sosiologi Agama) \\ ${ }^{3}$ IAKN Manado (Dosen Program Studi Psikologi Kristen)
}

Email: wolter22weol@gmail.com, nencyheydemans@iakn-manado.ac.id fiennylangi@iakn-manado.ac.id

\begin{tabular}{l}
\hline Info Artikel \\
Sejarah Artikel: \\
Diterima: 23 November 2020 \\
Direvisi: 27 Desember 2020 \\
Dipublikasikan: Januari 2021 \\
\hline e-ISSN: $2355-9527$ \\
p-ISSN: $2355-3308$ \\
\hline DOI: $10.51667 /$ tt.v8i1.474
\end{tabular}

\begin{abstract}
:
This paper describes the transformation of gratitude: identity and social relations during the Covid-19 pandemic era in Tomohon. The expression of gratitude to God Almighty (Opo Empung Wailan Wangko) was inherited from the ancestors of the Tou (people) of Minahasa for the yields obtained in the form of offerings. This one gratitude is done every one person in social relations and cultural integration. This article aims to analyze the transformation of gratitude carried out in Tomohon during the Covid-19 Pandemic era. This study reveals the social identity theory from the sociological paradigm by Steph Lawler (2014) which functions as a relationship between relatives as individuals, which in this study is called family, basudara. The article data uses field research with the method of observation and in-depth interviews. The results of the research are expected to help the government and society in preventing Covid-19 so as to minimize consumptive lifestyles and maintain distance. There are three values that are useful for building life, namely the value of brotherhood, mutual cooperation (mapalus) and spirituality.
\end{abstract}

Keywords: Gratitude Teacher, Identity, Social Relations, Covid-19 


\section{PENDAHULUAN}

Indonesia merupakan negara Pancasila dan Bhineka Tunggal Ika sebagai semboyannya. John A. Titaley (2020), menuliskan bahwa setiap orang memiliki dua identitas yakni identitas primodial dan identitas nasional. Menjadi orang Indonesia berarti menerapkan kesetaraan dan kemanusiaan kepada saudara yang berbeda suku, agama, ras dan budaya. Identitas nasional dan identitas primordial yang dimiliki bangsa Indonesia sejak diproklamasikan sebagai Negara Kesatuan Republik Indonesia sampai saat ini menjadi perjumpaan menuju transformasi yang humanis. Dua identitas yang memiliki nilainilai ke-Indonesia-an yang sangat luhur. Lebih dari itu, kemerdekaan dan kesetaraan melampaui perbedaan suku, agama dan sosial menjadi realita yang anti diskriminatif.

Identitas sosial pertama kali dipakai oleh Henri Tajfel sekitar tahun 1970-an dan John Turner sekitar tahun 1980-an. Identitas sosial merupakan konsep diri setiap individu yang disebabkan adanya interaksi dengan suatu kelompok sosial (Turner and Penny, 1986). Konsep teori identitas sosial merupakan cara memahami perilaku antar kelompok sosial (Taifel and Turner, 1979). Identitas sosial dalam pendekatan sosiologi menurut Steph Lawler yaitu identitas disusun dalam sebuah cerita relasi keluarga (basudara) dalam kehidupan manusia melalui kenangan, pengalaman, interpretasi, dan lain-lain dalam sebuah narasi. Paradigma naratif mengenai identitas dapat membentuk inti argumen. Melalui pelbagai cerita seperti kita memahami dunia dan hubungan kita dengan dunia itu, serta diri sendiri. Secara krusial, identitas diproduksi melalui karya otobiografi di mana manusia berkarya setiap hari. Karena itu, identitas bersifat sosial dan terus ditafsirkan kembali (Lawler, 2014).

Minahasa merupakan salah satu identitas primodial (suku) yang berada di Indonesia. Minahasa terletak di daerah Sulawesi Utara yang memiliki tradisi tahunan khas yakni ritual pengucapan syukur atau disebut foso rumages um banua. Ini menjadi tradisi tua Tou (orang) Minahasa sebagai wujud syukur atas berkat Opo Empung Wailan Wangko yang telah dikaruniakan bagi umat manusia. Rumages berasal dari kata rages yang artinya persembahan yang diberikan dengan ketulusan hati pada Opo Empung Wailan Wangko (Pinontoan, 2020).

Ada banyak foso dalam budaya Minahasa. Salah satunya foso rummages. Sebelum Kekristenan hadir di tanah Minahasa foso rumages merupakan ritual pemberian persembahan kurban (rages) kepada Opo Empung Wailan Wangko melalui leluhur. Biasanya ritual ini dilaksanakan sebagai ungkapan syukur atas panen disimbolkan dengan pemotongan babi kemudian ritual makan bersama dilaksanakan sebagai bentuk ungkapan syukur iman (Heydemans dan Pinontoan, 2020).

Saat kekristenan masuk di tanah Minahasa, foso rumages dipakai gereja dalam proses kontekstualisasi dan transformasi. Rupanya yang merayakan pengucapan syukur ini secara eksklusif orang-orang Kristen di tanah Minahasa. Ini disebabkan kekristenan itu dominan berada di Minahasa tetapi juga terdapat misalnya dari etnis Tionghoa, Jawa, dan sebagainya yang sudah terjadi saling-silang melalui perkawinan. Pengucapan syukur ini berkaitan dengan siklus fase menanam benih, memelihara dan panen. Pada saat panen dipertengahan tahun, orang Minahasa mengucap syukur sekaligus sebagai fase awal menanam padi yang baru (Kalangi dkk, 2012).

Pengucapan syukur mengalami transformasi. Orang mulai mengucap syukur atas berkat-berkat yang diperoleh dari pekerjaan-pekerjaan lain. Kemudian dimaknai sebagai hasil panen dari pekerjaannya. Budaya khas Minahasa ini membawa makna positif yakni sebagai sebuah pemersatu. Ini menjadi kekuatan sebuah bangsa yakni Bhineka Tunggal Ika di tengah kemajemukan bangsa Indonesia. 
Kesatuan ini tidak menghilangkan identitas etnik karena realitanya kita hidup dengan dua identitas yang memiliki hubungan timbal balik Indonesia menurut Indonesia (Titaley, 2013).

Pengucapan syukur di tanah Minahasa tahun 2020 diadakan berbeda dari tahun-tahun sebelumnya. Daerahdaerah yang merayakan pengucapan syukur seperti Minahasa, Minahasa Selatan, Tomohon, Manado, Bitung, dan Minahasa Utara menghadapi situasi yang baru. Hal ini disebabkan masyarakat global termasuk masyarakat yang berada di Tomohon menghadapi pandemi Covid-19 dengan tingkat resiko tinggi. Kota Tomohon masuk kategori zona merah penyebaran Covid-19. Berdasarkan surat edaran Wali Kota Tomohon No 174/wkt/VIII-2020 tentang pengucapan syukur kota Tomohon (Marentek, 2020), maka masyarakat merayakan ibadah pengucapan syukur bersama keluarga di rumah masing-masing, tidak menerima tamu dari luar daerah dan tidak membuat perayaan ucapan syukur di kebun. Aparat kelurahan dan daerah mengawasi ketat perayaan ini. Dari penelitian ini menunjukkan pandemi Covid-19 menjadi masalah serius dari semua elemen masyarakat tanpa membedakan budaya, agama dan status sosial. Merayakan pengucapan syukur sebagai bentuk rasa syukur hasil panen dan berkat tuntunan Tuhan pada manusia. Situasi transformasi terjadi dengan memperhatikan protokol kesehatan. Pelaksanaan pengucapan syukur diyakini tetap menjaga hubungan persaudaraan, gotong royong sebagai satu keluarga dan nilai kemanusiaan.

Pada umumnya, ritual pengucapan syukur atau foso rummages um banua merupakan perwujudan nyata dari kebudayaan Minahasa dan berfungsi sebagai pengikat tradisi sosial dan individu (Saruan, 1991). Oleh sebab itu, ritual merupakan bagian penting dari simbol dan aktivitas kehidupan manusia (Kertzer, 1988). Simbol mengandung makna perasaan dan perilaku yang membentuk disposisi pribadi dari para pemujanya.

Relasi sosial berkaitan dengan individualisme dan kolektivisme dalam hubungan kekerabatan (Steph, 2014). Relasi sosial dilihat Lawler sebagai bagian dari bingkai kekerabatan dalam hubungan antar individu. Kekerabatan membentuk identitas individu. Adapun dua bentuk relasi kekerabatan individu yakni pertalian darah dan kultur. Pertama, pertalian darah memiliki sifat alamiah yang diwariskan dari keturunan ayah dan ibu. Hubungan pertalian darah dibentuk secara genetik yang bermanfaat bagi kehidupan sosial. Kedua, Seseorang akan dikenal jika mengetahui dari mana ia berasal. Ini berkaitan dengan kultur. Kekerabatan dipahami sebagai ikatan kekeluargaan dan direkonstruksi berdasarkan konteks budaya. Salah satu contoh relasi sosial yang tejadi di masa pandemi Covid-19 yakni paradigma masyakarat tentang aktivitas dalam keluarga dengan belajar dari rumah, bekerja dari rumah dan beribadah dari rumah. Masyarakat saat ini mulai membangun konsep bahwa ikatan keluarga dapat diperluas menjadi agen transformasi dalam memori tiap individu dan memori kolektif yang ada dalamnya.

Kajian mengenai pengucapan syukur tidak bisa dipungkiri menarik dikaji dalam pendekatan sosiologi agama melalui relasi sosial yang masih dipertahankan dalam identitas Tou Minahasa di era pandemi Covid-19. Pendekatan ini selalu menarik untuk dikaji dalam perspektif yang berbeda. Zelika, Koagouw dan Tangkudung (2017), melakukan penelitian tentang perayaan pengucapan syukur di Minahasa berdasarkan pengalaman sebagai mahasiswa luar Sulawesi Utara di Fispol Unsrat. Dampak positif dari perayaan ini dapat memupuk dan memperkuat rasa solidaritas, gotong royong dan kekeluargaan sebagai orang Minahasa. Kemudian, dapat menjaga dan melestarikan budaya. Di sisi lain, pengucapan syukur mengandung unsur hedonis dan konsumeristik yang berlebihan. Sehingga 
tak jarang konflik sosial terjadi seperti keributan, perkelahian, dan pembunuhan yang disebabkan mengonsumsi alkohol berlebihan.

Perayaan pengucapan syukur yang dilakukan individu, keluarga dan masyarakat telah menjadi tradisi yang memerlukan pikiran, waktu, biaya dan tenaga dalam pelaksanaannya. Mononimbar (2020), menuliskan bahwa pengucapan syukur mengandung nilai pendidikan karakter yakni nasionalisme, gotong royong, religiusitas, kemandirian dan integrasi. Nilai-nilai ini mencerminkan semangat kebersamaan dengan memberikan membantu pada orang yang membutuhkan dan menjalani persaudaraan dan komunikasi melampaui agama, suku dan status sosial. Seringkali pengucapan syukur diikuti pemborosan dan pesta pora. Oleh sebab itu, tradisi ini perlu memumpuk sikap anti diskriminasi dan kekerasan melalui perjamuan makan dan minum dari keluarga dan membawa nasi jaha, dodol pada saat tamu tersebut hendak pulang.

Setelah menelaah hasil penelitian di atas, penulis tidak menemukan perayaan syukur dilaksanakan masa pandemi Covid19. Tulisan ini menjadi menarik dan unik kala Masyarakat kota Tomohon di tahun 2020 melaksanakan pengucapan syukur berdasarkan himbauan pemerintah dan gereja di era pandemi Covid-19. Meskipun dilaksanakan sederhana dengan tidak menerima tahu dari daerah luar Tomohon, namun pelaksanaan ini tetap terlaksana di setiap keluarga sebagai penanda identitas Tou Minahasa di masa sekarang.

\section{METODE PENELITIAN}

Tujuan dari metodologi pada penelitian ini yakni agar proses lebih teratur dan sistematis. Selain itu juga dengan adanya metodologi diharapkan akan mudah memahami perkembangan dan tingkat keberhasilan dari penelitian. Penelitian ini menggunakan metode kualitatif bersifat deskriptif yang bertujuan untuk memahami dan meneliti makna sekelompok masyarakat pada saat ini (Sugiyono, 2007).
Penelitian ini berfokus pada tokoh agama, budayawan dan sebagian masyarakat kota Tomohon yang melaksanakan pengucapan syukur. Oleh karena itu, penelitian ini menggunakan studi sosiologi agama dalam rangka memaknai masyakarat sebagai subjek. Studi sosiologi agama adalah sebuah metode yang menganalisis relasi antara manusia termasuk juga aspek sosial, budaya dan ekonomi. Metode ini mengarah pada fenomena di mana setiap tindakan manusia memiliki hubungan antar manusia sebagai agen perubahan (Rustandi, 2020). Pemilihan informan dilakukan secara purposif dan disesuaikan dengan kebutuhan penelitian berdasarkan masalah, peristiwa dan realita (Creswell, 2015). Agar supaya pembaca bisa mendapat pemahaman yang baru (Raco, 2010).

Teknik pengumpulan data yang digunakan yaitu observasi partisipasi dan wawancara mendalam dengan beberapa informan melalui teknik purposive sampling. Informan adalah tokoh agama, budayawan, dan masyarakat. Dengan menggunakan teknik pengumpulan data ini maka penelitian mengarahkan pada masyarakat sebagai agen transformasi dalam konteks budaya Minahasa merayakan pengucapan syukur serta mengantisipasi penyebaran Covid-19 skala global dan lokal.

Observasi dilakukan pada tanggal 20 September 2020 sampai 27 September 2020 dan 4 Oktober 2020 sampai 11 Oktober 2020. Adapun manfaat dilakukannya wawancara yaitu dapat menggali informasi berkaitan dengan pengucapan syukur di Tomohon pada masa pandemi Covid-19 . Dengan adanya kedua teknik pengumpulan data ini maka penelitian mengarah pada masyarakat Tomohon sebagai agen perubahan dalam konteks budaya lokal serta berkontribusi mematuhi protokol kesehatan memerangi penyebaran Covid-19 skala global.

\section{HASIL DAN PEMBAHASAN}

Perayaan pengucapan syukur di kota Tomohon dilaksanakan serentak pada 
tanggal 9 Agustus 2020. Pengucapan syukur tahun ini dimaknai berbeda dengan tahun-tahun sebelumnya. Licky Palar (LP), mengatakan bahwa di tengah pandemi Covid-19 seluruh jemaat tidak datang di gedung gereja untuk mengikuti ibadah. Semua anggota jemaat mengikuti ibadah melalui live streaming, pengeras suara dan mengajak jemaat untuk mengungkapkan rasa syukur melalui sampul persembahan syukur yang akan dijemput oleh setiap pelayanan khusus (pelsus) kolom di rumah masing-masing. Makna ungkapan pengucapan syukur diberikan guna menunjang pelayanan di jemaat dalam program pelayanan jemaat GMIM Siloam Taratara. Mengingat selama pandemi pendapatan kas jemaat menurun drastis. Hal ini disebabkan banyak anggota jemaat yang kehilangan pekerjaan dan atau hasil perkebunan kurang pembeli di pasar sehingga menurunkan perekonomian keluarga atau jemaat. Dengan memberi sampul persembahan syukur dan beribadah dari rumah maka inilah makna pengucapan syukur di masa pandemi Covid-19.

Transformasi perayaan pengucapan syukur terjadi disebabkan adanya kesadaran dan sikap manusia untuk taat anjuran pemerintah, gereja dan protokol kesehatan. Salah satu transformasi pengucapan syukur yang tejadi adalah tidak mengadakan pertemuan dengan jumlah yang besar baik di rumah, kebun dan tempat ibadah. Ini menjadi solusi mengurangi dan mencegah penyebaran Covid-19. Masyarakat membangun jejaring bersama gereja, pemerintah dan budaya untuk melakukan transformasi tanpa pesta atau acara yang besar. Sebagai konsekuensi, masyarakat melakukan transformasi pengucapan syukur dengan ucapan syukur, hormat atas berkat Tuhan dengan tidak menundang sanak saudara di daerah lain. Relasi sosial tetap terjaga meskipun hanya sebatas keluarga dari rumah masing-masing dan atau menggunakan media virtual sebagai penanda identitas Tou Minahasa yang tetap melaksanakan pengucapan syukur di tengah situasi pandemi Covid-19.
Meskipun mengalami transformasi, perayaan pengucapan syukur perlu dirawat, dilestarikan dalam memori kolektif.

Pengucapan syukur di tahun 2020 budayawan Denni H. R. Pinontoan (DP) mengatakan menjadi ekspresi religikultural yang diwariskan turun-temurun dari nenek moyang Tou Minahasa dan kekristenan. Ekspresi ini tidak identik dengan pesta pora, mabuk-mabukan dan konsumerisme yang berlebihan. Itu berarti transformasi sedang berlangsung sebagai identitas Tou Minahasa melalui perayaan yang dilakukan dengan sikap sederhana, kekeluarga, persatuan dan spirit untuk mengucap syukur dalam segala hal. Sebelumnya dalam perayaan pengucapan syukur kental terasa sikap membantu (mapalus) sesama keluarga dan tetangga untuk makan bersama. Akan tetapi tahun ini, dibatasi mapalus hanya berlaku sesama anggota keluarga di dalam rumah. Ini untuk menghindari kerumuman di suatu tempat.

Menurut DP, pengucapan syukur di tahun 2020 memang sebaiknya dilakukan di rumah. "Baku pasiar" dan open house untuk tahun ini sebaiknya tidak dilakukan karena berpotensi dapat menimbulkan kerumunan banyak orang dan beresiko tertular Covid-19. Ini sesuatu yang sulit bagi orang Minahasa Kristen di Sulawesi Utara yang dalam tradisi kultural keagamaannya, perayaan pengucapan syukur adalah pesta. Sebagai pesta maka identik dengan makan-minum, "baku pasiar", "maso gereja" dan kumpulkumpul. Akan tetapi, ini akan menjadi model transformasi keagamaan yang khas dan baru pertama kali dilaksanakan dalam pembatasan perkumpulan orang melalui pembatasan aktivitas pengucapan syukur di masa pandemi Covid-19.

Terjadi kontruksi makna pengucapan syukur di masa pandemi Covid-19. Menurut Daniel Aldeich (2015), untuk mencegah penularan virus bukan jarak sosial (social distancing) yang dihindari melainkan jarak fisik (physical distancing). Karena itu, istilah jarak sosial menimbulkan kontraproduktif. Seharusnya 
dalam kondisi pandemi yang dipandemi penguatan ikatan sosial sangat penting untuk mengatasinya bersama. Kekuatan persatuan dalam ikatan sosial identitas bersama menjadi spirit mengucap syukur melalui menjaga jarak fisik. Istilah ini kemudian diadopsi oleh WHO dengan merevisi dari jarak sosial menjadi jarak fisik. Keputusan yang diambil WHO untuk mengantisipasi masyarakat agar tetap menjaga jarak fisik bukan jarak sosialnya (Djalal, 2020). Artinya, walaupun tidak ada kontak fisik antara sesama (teman, keluarga, tetangga), tetapi relasi sosial tetap dibina dan tetap terjaga harmonis.

Feliks Terok (FT) mengungkapkan pengucapan syukur tahun ini berbeda dengan perayaan di tahun sebelumnya. Biasanya, perayaan satu tahun sekali yang dirayakan dipertengahan tahun merupakan moment berkumpulnya keluarga yang berada di jauh datang di Tomohon, teman sekerja di proyek bisa datang berkumpul dalam suasana kekeluargaan sedarah meskipun tidak bersaudara. Biasanya anggaran yang dikeluarkan sekitar Rp. 2.000.000. Makanan yang disajikan berlimpah. Di situlah terjadi interaksi sosial dalam suasana makan bersama. Akan tetapi, tahun 2020 pengucapan syukur dilaksanakan di rumah masing-masing dan sedikit anggaran makanan yang dikeluarkan. Ini disebabkan tidak ada tamu yang datang di rumah.

Walikota Tomohon, Jimmy F. Eman menerbitkan Surat Edaran No. 174/WKT/VIII/20 tanggal 3 Agustus 2020 tentang perayaan pengucapan syukur kota Tomohon yang dilaksanakan pada hari Minggu 9 Agustus 2020 untuk tidak melakukan pesta pora, tidak mengundang tamu dari luar kota Tomohon, tidak berjabat tangan, tidak menyediakan minuman keras termasuk tidak melaksanakan pesta di kebun. Ini dimaksudkan agar dapat meminimalisir penularan dan penyebaran Covid-19.

FT mengatakan pengucapan syukur dilaksanakan berdasarkan surat edaran Walikota Tomohon tahun 2020, kemudian
Badan Pekerja Majelis Sinode (BPMS) GMIM mengeluarkan himbauan agar masyarakat dan jemaat beribadah dari rumah masing-masing dan tidak dipusatkan di rumah ibadah. Ibadah disiarkan melalui pengeras suara dan live streaming. Ini menjadi perhatian khusus bagi jemaat untuk melaksanakan pengucapan syukur berdasarkan himbauan pemerintah dan gereja. Baginya, perayaan pengucapan syukur dilakukan dengan tidak pesta pora, namun penuh kesederhanaan bersama keluarga di rumah dan tidak menerima tamu. Makanan disediakan untuk konsumsi keluarga di rumah. Sehingga banyak kelebihan makanan yang bisa dimakan sampai dua hari lamanya. Makanan ini selain dibeli dari pasar, tetapi ada juga hasil sayur-sayuran dari kebun untuk diolah menjadi makanan keluarga. Tidak lupa memberikan sampul pengucapan syukur di gedung gereja sebagai bagian dari berkat Tuhan dalam pekerjaannya. Di sisi lain, terdapat pembatasan gerak orang yang masuk di kota Tomohon dengan diperketat penjagaan satgas Covid-19 dan linmas. Mereka berjaga-jaga untuk setiap kendaraan yang akan masuk di kelurahan. Bagi pendatang keluarga yang tinggal di luar kelurahan tidak diperkenankan masuk oleh linmas untuk bertamu.

Masyarkat merupakan suatu realitas eksternal yang dapat menentukan hasil individu. Pada dasarnya masyarakat dapat menentukan hasil individu sekaligus identitas individu. Karena itu, identitas sosial didasarkan pada identifikasi individu dengan masyarakat atau kelompok sosial. Terjadi proses perbandingan dan kategorisasi sosial yang dilabeli merasa diri bersama dengan individu berada dalam grup. Sebaliknya, hal yang berbeda dilabeli berada di luar grup. Kategori ini terjadi agar setiap individu dapat memiliki cara berpikir dan bertindak yang sama sebagai anggota kelompok sosial (Burke dan Stets, 2009). Ini menunjukkan bahwa identitas suatu kelompok menjadi bentuk keseragaman bertindak yang kuat dalam memobilisasi setiap individu. Lawler menambahkan 
bahwa identitas bukan hanya milik individu melainkan diproduksi antar individu dalam hubungannya dengan lingkungan sosial.

Pengucapan syukur merupakan ritual identitas yang telah dilakukan oleh para leluhur sebagai wujud berkat-Nya yang telah dikaruniakan bagi umat. Menurut Rinto Taroreh, ritual ini menyajikan berbagai bentuk persembahan seperti persembahan ja se weteng (simbol persembahan kepada para leluhur). Puncak diadakan ritual ini sebelum matahari terbit sebagai simbol pekerjaan akan dilakukan dengan penuh semangat kerja yang baru. Ketika matahari terbit di pagi hari, para leluhur mengundang masyarakat lain dari luar kelurahan (roong) dan masyarakat yang kebetulan lewat di kelurahan untuk turut menikmati berkat makanan yang ada secara bersama-sama. Ritual ini mengalami transformasi sejak kedatangan penginjilan dari dunia Barat di tanah Minahasa. Graafland (1991), mulai mentransformasikan tradisi rummages ke tradisi kekristenan di akhir 1800-an. Makna transformasi terlihat dalam membawa persembahan syukur di gereja apakah dalam bentuk hasil panen di perkebunan maupun sampul syukur dari hasil pekerjaan lainnya sambil mengundang sanak-saudara dalam perkumpulan syukur iman atas hasil panen. Hal yang unik terjadi di tahun 2020, pengucapan syukur mengalami model transformasi baru. Masyarakat kota Tomohon tidak mengadakan perkumpulan yang melibatkan banyak orang dan menggunakan protokol kesehatan di masa pandemi.

Bagi Nona Pangemanan (NP) pengucapan syukur tahun 2020 merupakan perayaan unik yang tidak melibatkan saudara dari luar kota Tomohon. Karena itu, ia bersama keluarganya merayakan pengucapan syukur di kebun sambil makan bersama. Makanan yang disajikan berasal dari hasil tanaman di kebun seperti jagung manis, ubi, pisang dan aneka sayur yang dimasak dalam bulu. Makan bersama keluarga di kebun menjadi momen tersendiri dengan mengucap syukur kepada
Tuhan yang memberikan hasil dan berkat bagi keluarganya. Makan sambil menikmati alam ciptaan Tuhan yang begitu luar biasa indahnya. Di sisi lain, merayakan pengucapan syukur di kebun menjadi ajang perkumpulan sanak-saudara yang tinggal di kota Tomohon. Ada beberapa orang tidak menggunakan masker. Tanggapan NP bahwa perayaan ini dilaksanakan di alam terbuka dan yang datang adalah sanak saudara. Selain itu, mereka mencuci tangan dari mata air yang mengalir di kebun.

Pelaksanaan acara di kebun melalui suasana alam kota Tomohon yang dingin dan sejuk, bukan menjadi pertama kali bagi NP. Di tahun 2020, masa Covid-19 ia bersama saudaranya datang ke kebun merayakan ulang tahun pernikahan. Mereka tidak menerapkan protokol kesehatan secara ketat. Di mana terjadi kerumunan (banyak orang) dan ada beberapa orang tidak menggunakan masker. Hal ini beresiko terjadi penyebaran dan penularan Covid-19.

Meskipun ada larangan pemerintah untuk keluar rumah termasuk pergi ke kebun dengan mengumpulkan banyak orang dalam merayakan pengucapan. Akan tetapi ada ekspresi religi dan budaya tidak menjadi penghalang bagi NP untuk merayakan dengan penuh kesadaran dengan keluarga internal sambil mengabaikan protokol kesehatan. Bagi keluarga yang berada di luar kelurahan, NP membagikan kegiatan di kebun melalui akun FB-nya. Ada juga, komunikasi dibangun melalui video call dengan melihat dan bersyukur atas perkebunan keluarga di masa pandemi ini.

Meskipun dalam situasi pandemi Covid-19, perayaan pengucapan syukur di kota Tomohon tetap terlaksana dengan berbagai varian tempat pelaksanaannya. Tradisi ini sudah berakar dalam sistem budaya Minahasa dan diwariskan sampai saat ini. LR, DP dan FT melaksanakan pengucapan syukur dari rumah masingmasing sesuai berkat yang Tuhan berikan. Sambil tidak lupa untuk mengucap syukur dalam segala hal termasuk di situasi 
pandemi ini. Di sisi lain, NP mengadakan pengucapan syukur bersama keluarga di kebun. Meskipun ada larangan pemerintah untuk tidak melaksanakan pengucapan syukur di kebun dan melibatkan banyak orang sehingga terjadi kerumunan. Namun NP tetap melakukannya dalam perayaan sukacita atau pesta.

\section{KESIMPULAN}

Ritual pengucapan syukur atau foso rumages um banua merupakan tanda perjumpaan antara agama tua Minahasa dengan kekristenan. Kontekstualisasi dan transformasi dari pengucapan syukur dilakukan oleh gereja. Ini sudah menjadi tradisi yang berakar dalam sistem religi Minahasa. Pengucapan syukur di masa pandemi Covid-19 merupakan konteks yang baru di dalamnya ada pembatasan dan ketakutan massal yang berdampak pada terbatasnya pertemuan antar keluarga. Pengucapan syukur dibuat meskipun hanya untuk internal keluarga. Artinya, pengucapan syukur di Tomohon merupakan ekspresi religi, kultutal dan sosial yang tidak diucapkan oleh kebanyakan orang bahwa pengucapan identik dengan pesta pora dan konsumerisme. Orang (Tou) Minahasa menerapkan model baru dalam perayaan pengucapan syukur dengan cara tidak dalam perkumpulan yang melibatkan banyak orang dan menerapkan protokol kesehatan bersama keluarga inti. Pengucapan syukur menjadi perayaan yang berdimensi sosial, religi dan kultural. Nilainilai yang bermakna di dalamnya terdapat mapalus (saling membantu), persaudaraan dan spiritualitas untuk mengucap syukur.

\section{UCAPAN TERIMA KASIH}

Penelitian ini dianggarkan melalui dana hibah IAKN Manado tahun 2020. Karena itu penulis mau ucapkan terima kasih kepada Rektor IAKN Manado, Dr. Jeane M. Tulung, M.Pd, reviewer dan LP2M IAKN Manado yang telah memberikan kesempatan dalam penelitian ini dengan memberikan bantuan selama proses penelitian dan memberikan masukan-masukan yang bermanfaat. Penulis juga mengucapkan terima kasih kepada Tuhan Yang Maha Esa dan semua pihak yang mendukung penelitian ini sehingga bisa terlaksana dengan baik.

\section{DAFTAR PUSTAKA}

Aldrich, D. P. dan Sawada Y. "The Physical and Social Determinants of Mortality in the 3.11 Tsunami." Social Science and Medicine, 124 (1), 2015.

Burke, Peter J. dan Jan E. Stets, Identity Theory. New York: Oxford University Press, 2009.

Cresswell, Jhon W. Research Design. London: Sage Publication, 2015.

Djalal Farah Mutiasari, "Asosiasi Kata 'Sosial' Vs. 'Physical' Distancing." Jakarta: Binus University Faculty of Humanties, 2020.

Graafland, N. Minahasa: Negeri, Rakyat dan Budayanya. Jakarta: Pustaka Utama Grafiti, 1991.

Heydemans, Nency Aprilia dan Denni H. R. Pinontoan, "Ritual Mahtambulelen dan Kekristenan di Minahasa" dalam Izak Y. M. Lattu dan Tedi Kholiludin (Ed.). Agama dan Budaya Nusantara Pasca Kristenisasi. Semarang: Lembaga Penelitian Sosial dan Agama eLSA Press, 2020.

Ingkiriwang-Kalangie, dkk. Upacara Tradisional yang Berkaitan dengan Peristiwa Alam dan Kepercayaan Daerah Sulawesi Utara (Sulawesi Utara: Departemen Pendidikan dan Kebudayaan, 2012.

Jenkis Richard, Social Identity. New York: Routledge, 2008.

Kertzer, D. I. Ritual, Politic and Power. New Heaven and London: Yale University Press, 1988. 
Lawler, Steph. Identity: Sociological Perspentives. Cambridge: Polity Press, 2014.

Marentek, Hesly. 2020. "Pengucapan Syukur Kota Tomohon Minggu 9 Agustus 2020, Tidak Menerima Tamu, Ini Pesan Walikota”. Diakses dari

https://www.tribunmanado.com. Publikasi pada 10 Agustus 2020.

Mononimbar Stevi K.S. "Hubungan Tradisi Pengucapan Syukur dengan Nilai PPK (Penguatan Pendidikan Karakter).” 2019. Diakses dari https://lpmpsulawesiutara.kemdikb ud.go.id. Publikasi pada 14 Agustus 2020.

Raco, J. R. Metode Penelitian Kualitatif. Jakarta: PT. Grasindo, 2010.

Rustandi, Arip. "Ruang Lingkup Geografi.” 2011. Diakses dari https://geografi-arip.blogspot. com/2011/publication pada 14 Agustus 2020.

Saruan, Josef Manuel. Opo dan Allah Bapa: Suatu Studi Mengenai Perjumpaan Agama Suku dan Kekristenan di Minahasa. Disertasi. Jakarta: The South East Asia Graduate School of Theology, 1991.

Sugiyono. Memahami Penelitian Kualitatif. Bandung: Alfabeta, 2007.

Tajfel $H$ and Turner, J. C. "An integrative theory of intergroup conflict". Dalam W. G. Austin \& S. Worchel. The social psychology of intergroup relations. Monterey, $\quad C A$ : Brooks/Cole, 1979.

Titaley, Jhon A. Religiositas di Alinea Tiga. Salatiga: Satya Wacana University Press, 2013.

Titaley, John A. Berada dari Ada Walau Tak Ada: Indonesia Sebagai Konteks Kehidupan Beragama. Semarang: Elsa Press, 2020.

Turner John and Oakes, Penny. "The significance of the social identity concept for social psychology with reference to individualism, interactionism and social influence".
British Journal of Social Psychology. 25 (3), 1986.

Turner, J. C. and Reynolds, K. J. The story of social identity. Dalam T. Postmes \& N. Branscombe. Rediscovering Social Identity: Core Sources Psychology Press, 2010.

Zelika Aprilia, Ferry V. I. A. Koagouw, J. P. M. Tangkudung. Persepsi tentang Perayaan Pengucapan Syukur Minahasa (Studi Komunikasi Antar Budaya pada Mahasiswa Luar Sulawesi Utara di Fispol). Jurnal Acta Diurna Komunikasi. 6 (1), 2017. 